\title{
Annual cycle of the mexican ground squirrel (Xerospermophilus perotensis)
}

Sandra H. Montero-Bagatella ${ }^{1 *}$, Alberto González-Romero ${ }^{1}$, Gerardo Sánchez-Rojas ${ }^{2}$ and Sonia Gallina 1 .

${ }^{1}$ Red de Biología y Conservación de Vertebrados, Instituto de Ecología A. C. Carretera Antigua a Coatepec No. 351, El Haya, CP. 91070, Xalapa. Veracruz, México. Email: helena.bagatella@gmail.com (SHMB), alberto.gonzalez@inecol.mx (AGR), sonia. gallina@inecol.mx (SG).

${ }^{2}$ Laboratorio de Biología de la Conservación, Área Académica de Biología. Universidad Autónoma del Estado de Hidalgo, Ciudad del Conocimiento S/N, Km 4.5 de la Carretera Pachuca-Tulancingo, Col. Taxistas, Mineral de la Reforma, CP. 42184 Pachuca, Hidalgo, México. Email: gerardo.sanchezrojas@gmail.com (GS-R).

* Corresponding author

Seasonality and changes in climate and habitat dynamics lead ground squirrels to use resources during the most favorable seasons and avoid less favorable conditions by hibernating. The Perote ground squirrel (Xerospermophilus perotensis) is nationally and internationally classified as vulnerable to extinction; however, our knowledge of this species is scant. The aim of this study was to describe and analyze its annual cycle. Temperature and rainfall data (2008 to 2014) for the area were used. Animal frequencies were obtained for seven sites by capture-markrecapture; captured animals were marked, and their sex, weight, age and reproductive status noted. Population structure was obtained for each site using the male:female sex ratio and age structure. Activity during the annual cycle is statistically associated with temperature. Scrotal males were most abundant while females with signs of pregnancy and those lactating were recorded least often. The number of adults and juveniles differed statistically, with adults more abundant throughout the study. Weight varied throughout the study, and differed between adults and juveniles. The Perote ground squirrel exhibits phenological patterns similar to those of species of the genus Spermophilus, which respond to changes in temperature and its activity cycle begins in spring and ends in autumn. The weight of the squirrels was dynamic, probably resulting from reproduction, hibernation and their response to changes in environmental resources. The frequency of this species was low, with few juveniles recorded, indicating that $X$. perotensis is facing serious problems, likely from severe anthropogenic pressure and its own ecological characteristics.

La estacionalidad y dinamismo del clima y hábitat inducen a que las ardillas terrestres exploten los recursos en las mejores estaciones y eviten la menos favorable a través de la hibernación. La ardilla endémica de Perote (Xerospermophilus perotensis) se encuentra clasificada a nivel nacional e internacional como vulnerable a la extinción, ya que su hábitat se ha reducido drásticamente por lo que su conservación se ha visto comprometida, a pesar de esto el conocimiento acerca de la especie es escaso. El objetivo de este estudio fue describir y analizar la fenología de la especie. Se obtuvieron las temperaturas y precipitaciones del área de estudio del año 2008 al 2014; la frecuencia de capturas se obtuvo a través del método de captura-marcaje-recaptura. Los animales capturados fueron marcados y se registró el sexo, edad, peso y estado reproductivo en el que se encontraban. La estructura poblacional se obtuvo para cada sitio usando la proporción de sexos, edad y estado reproductivo. Los resultados indicaron que la actividad durante el ciclo anual está relacionada estadísticamente con la temperatura, ya que cuando desciende ocurre la hibernación; así como de las condiciones reproductivas debido a que se presentaron cuando las temperaturas fueron las más altas. En lo que respecta a las características reproductivas, los machos escrotados fueron los más abundantes y las hembras con signos de preñez o lactantes fueron las menos registradas. Para la categoría de edad, el número de adultos y juveniles difirieron estadísticamente, siendo los adultos los más abundantes. Con relación al peso de las ardillas, fue variable a lo largo del estudio y sólo existió diferencia estadística entre el peso de los adultos y juveniles. La ardilla de Perote exhibe patrones fenológicos similares a las del género Spermophilus, ya que la especie responde a los cambios de temperatura y la actividad de su ciclo empieza en la primavera y termina en el otoño. El peso de los organismos fue dinámico, probablemente causado por la reproducción, hibernación y por su respuesta a los cambios en los recursos ambientales. En general, las frecuencias de los organismos fueron bajas y con pocos registros de juveniles, lo que indica que la especie está enfrentando serios problemas para persistir debido a las severas presiones antropogénicas a las que se enfrenta y a sus propias características ecológicas.

Key words: ground squirrel; hibernation; phenology; reproductive characteristics; temperature.

๑ 2018 Asociación Mexicana de Mastozoología, www.mastozoologiamexicana.org

\section{Introduction}

Climate and habitat conditions are dynamic, so organisms avoid or mitigate the effects of the least favourable times of the year through migration, aestivation or hibernation, taking advantage of the season that favors their development and reproduction (Bradshaw and Holzapfel 2007; Williams and Lane 2014). The timing of these events and their relationship to the different stages of life are induced by abiotic forces such as light, temperature and seasonality (Michener
1983; Williams et al. 2014) and by biotic forces such as hormone levels (Bradshaw and Holzapfel 2007).

In ground squirrels, annual cycles are marked and divided into an active and an inactive phase, the durations of which vary by species, sex, age, latitude, climate and habitat (Michener 1983; Williams and Lane 2014; Williams et al. 2014). Reproductive cycles, gestation, lactation, emergence of juveniles, fat storage and preparation for hibernation occur during the active phase and hibernation 
occurs during the inactive phase (Michener 1983). Some annual events are critical for ground squirrels, such as the day that they emerge from hibernation. Males who emerge late have less chance of acquiring territory and a decreased possibility of developing the secondary sex characteristics required for reproduction. Late emergence by females can affect their weight because after reproducing (gestation and lactation), they must accumulate enough fat to hibernate (Williams and Lane 2014).

The reproductive season in Sciuridae, the family to which the ground squirrels belong, coincides with peak food availability. So, if these two events go out of phase, reproductive rates and survival could decrease and cause serious imbalances in the population, and even lead to extinction (Michener 1983; Miller-Rushing et al. 2010; Lane et al. 2012). Repeated observation of the population structure (sex ratio, age category and reproductive status) allows us to understand the relationship between the annual cycle and demography, since both are sensitive to time and can provide information about the viability and state of the populations. It is generally understood that five to ten years of observations are necessary to obtain sufficient information about these parameters (Van Horne 1983; Caughley 1977; Miller-Rushing et al. 2010).

The endemic ground squirrel of Perote (Xerospermophilus perotensis) is diurnal, social, terrestrial and mainly herbivorous (Best and Ceballos 1995; Castillo-Castillo and González-Romero 2010). Its reproductive period begins in May and ends in August. Gestation lasts 30 days and females have an average of four kits (Yensen and Sherman 2003). Hibernation occurs from the end of October to March, interrupted by short feeding periods (Valdez and Ceballos 2003; Castillo-Castillo 2009). These animals prefer to live in open treeless, shrubless areas with short grasses (Yensen and Sherman 2003; Hannon et al. 2006; MonteroBagatella et al. 2017), though they have also been recorded in areas with shrubs and in crops (Best and Ceballos 1995; Mendoza-Carreón 2009). This species is facing conservation problems resulting from the intense development and extreme transformation of its habitat by humans, which has spared only $30 \%$ of its original habitat (Sánchez-Cordero et al. 2005). Currently, this species is classified as threatened in Mexico (Official Mexican Standard NOM-059-SEMARNAT-2010; SEMARNAT, 2010) and as endangered by the International Union for the Conservation of Nature (IUCN; Álvarez-Castañeda et al. 2008).

Because the Perote ground squirrel is extremely vulnerable, we decided to describe and analyze its annual cycle and learn about the relationship between climate conditions and the population dynamics of this species. The information obtained will allow us to understand the ecology of this species and provide the tools necessary to understand what is necessary for its protection and conservation. Combined with legal action, this could lead to the preservation of the species.

\section{Materials and Methods}

Study Area. The study was done in the Perote Valley, located in the municipality of Perote, Veracruz, Mexico. This valley is located between two mountain ranges, the Sierra Norte of Puebla and the Cofre de Perote, both of which offer unique environmental conditions that have resulted in the presence of several endemic species (Best and Ceballos 1995; Sánchez-Cordero et al. 2005). These species are facing severe conservation problems owing to intensive agricultural practices (both crops and livestock) that have fragmented and decreased the limited available habitat in the region (Gerez-Fernández 1985; Arriaga et al. 2000). The elevation of the study sites is 2,300 to 2,700 masl. The climate is the most humid of the semiarid climates, with a mean annual temperature of $14{ }^{\circ} \mathrm{C}$ and a mean annual precipitation of $500 \mathrm{~mm}$ (Gerez-Fernández 1985; Medina and Angulo 1990). The vegetation is diverse: pine-oak forest (Pinus spp. and Quercus spp.), Juniper forest (Juniperus deppeana), scrub (Yucca periculosa, Nolina parviflora), natural meadows (Scleropogon brevifolius, Erioneuron avenaceum) and induced pastures (Muhlenbergia quadridentata, Aristida divaricata), along with halophytic vegetation (Bouteloua scorpioides, Atriplex linifolia; Gerez-Fernández 1985; Delgadillo 2011).

Seven sites were sampled, differing mainly in their plant associations and the time they have been protected from livestock management (Figure 1). The composition of the vegetation was obtained from the study of Montero-Bagatella et al. (2017). Site 1 was on a basalt flow with short grass pastures and sparse tussocks of Aristida harvadii and Sclerepogon brevifolius. Site 2 was located $200 \mathrm{~m}$ from the Veracruz-Mexico City highway, with native plants like Jarava ichu and Bidens anthemoides and no agricultural activity. Site 3 was located approximately $500 \mathrm{~m}$ from the same highway, furrowed from past agricultural activities, with Aristida divaricata as the dominant plant species. Site 4 was close to the Perote-Amozoc highway, with predominantly short tussocks of grasses like Jarava ichu $(20 \mathrm{~cm})$ and occasional pasturing of goats and sheep. Site 5 was adjacent to Site 4, with irregular soil owing to management practices to prevent erosion; some shrubs interspersed among its moderately long grasses, in dense tussocks, such as Jarava ichu. Although this site has been reforested and is to be used for conservation, livestock is still pastured on it. Site 6 is an area where crop farming was abandoned about 14 years ago and has been used as a succession of native pastures with J. ichu and Bouteloua scorpioides, some succulents and shrubs. It is surrounded by an electric fence and barbed wire and is under surveillance to prevent grazing by intruding domesticated animals. Site 7 has patches of short grass like Aristida harvadii and some bunches of other types of grasses such as Bouteloua scorpioides, but has not been subjected to any agricultural activities in the last four years and is also under the same type of surveillance as site 6 .

Study Design and Data Collection. To capture the squirrels, two plots ( $1 \mathrm{ha}$ ) separated by $100 \mathrm{~m}$ were set up in each 


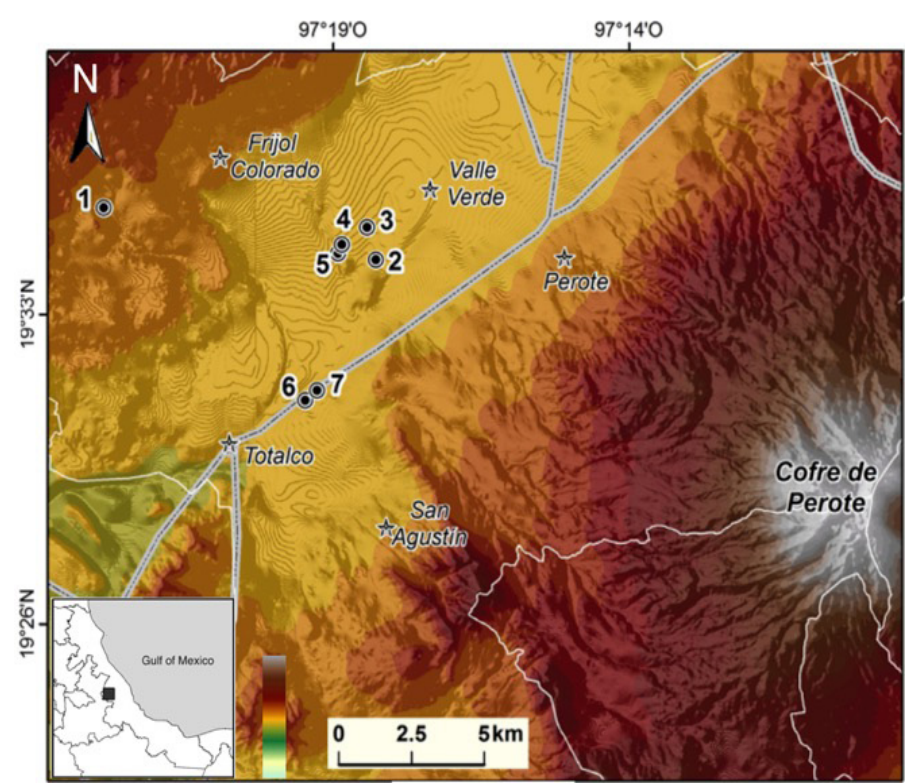

Figure 1. Study area with the sites where sampling was conducted. The seven study sites are shown and main towns are indicated with a star. More intense colors indicate a higher altitude

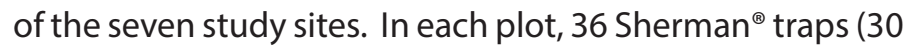
$x 10 \times 8 \mathrm{~cm}$ ) were set up in a grid ( $6 \times 6$ traps), separated by $20 \mathrm{~m}$. The traps were baited with oat flakes and peanut butter and were active from 0830 to $1500 \mathrm{~h}$ (Gurnell and Flowerdew 2006; Castillo-Castillo 2009). Each plot was active for three consecutive days (Jones et al. 1996; Castillo-Castillo 2009; Montero-Bagatella and González-Romero 2014) for each month during the ground squirrels' activity cycle from June 2008 to June 2014. The animals captured were marked using magnetic chips (MUSSICC Chips-AVID ${ }^{\circledR}$ ), and their sex, weight and reproductive status were noted (e.g., in males scrotal testes and in females mammary glands that indicate pregnancy or lactation; Gurnell and Flowerdew 2006; Castillo-Castillo 2009). The animals were later released in situ (Sikes et al. 2016). Animals weighing more than $170 \mathrm{~g}$ or exhibiting reproductive characteristics were considered as adults (Dimmick and Pelton 1996; Gurnell and Flowerdew 2006; Castillo-Castillo 2009) and those weighing less or without these characteristics were considered juveniles (Castillo-Castillo 2009). Population structure was obtained for each site using sex ratio (males and females) and age (Caughley 1977). Temperature and precipitation data for the study period were provided by the National Water Commission (Comisión Nacional del Agua; CONAGUA).

Statistical Analysis. To carry out the statistical analyses, based on the reported frequencies of the ground squirrels, the years were divided into three periods: pre-reproductive (April and May), reproductive (June to July) and post-reproductive (September, October). Averages of monthly temperature and precipitation data were analyzed using oneway ANOVAs, with post hoc Newman-Keuls tests (Zar, 1999). Sex characteristics were analyzed using a chi-squared test (Zar, 1999). All of the analyses were run in Statistica 10.0.

\section{Results}

The number of animals captured, monthly precipitation and temperature for 2008 to 2014 are shown in Figure 2. Total sampling effort was 12,528 trap days (Table 1 ). The highest abundance values mostly coincide with the peaks in temperature and precipitation, decreasing when these variables decreased. The year of 2008 was atypical, it was very rainy and hot, with more than $350 \mathrm{~mm}$ of rain and temperatures above $30^{\circ} \mathrm{C} ; 2009$ and 2010 were also very rainy. The highest peaks in rainfall are reported from August onward and decreased in October with little rain in the following months. The mean temperature throughout the study was $22.2^{\circ} \mathrm{C}$. The highest temperatures were recorded in March-April, with lower temperatures in August and the lowest from November to January, as low as $13^{\circ} \mathrm{C}$ for this period in 2014, which was the coldest year of the study. There were statistically significant differences in temperature during the three periods of the ground squirrel's reproductive cycle $(\mathrm{F}=10.70, \mathrm{~d} . \mathrm{f} .=21, P=0.0006)$. The post hoc test detected differences between the temperatures of the post-reproductive period and those of the pre-reproductive period $(P=0.0004)$ and between the temperatures of the pre-reproductive period $(P=0.03)$. Precipitation did not differ significantly among the different phases of the reproductive period $(\mathrm{F}=3.3, \mathrm{~d}$. $\mathrm{f} .=21, P=0.05)$.

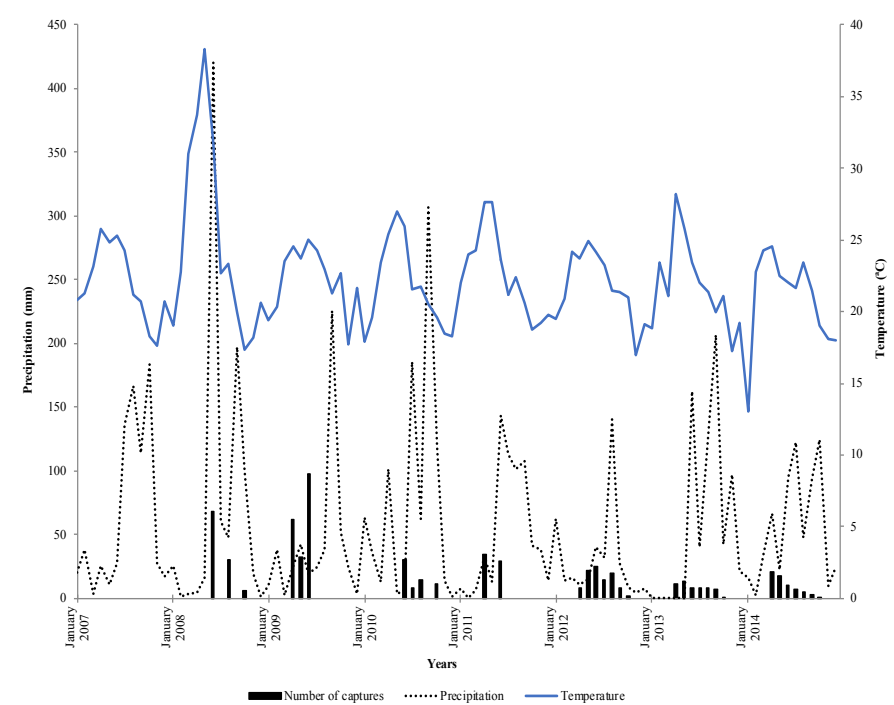

Figure 2. Mean monthly temperature and precipitation for Perote, Veracruz, Mexico 2008 - 2014. The number of captures of the Perote ground squirrel (Xerospermophilus perotensis) is also shown. Black bars = number of captures, blue line = temperature, point line $=$ precipitation .

In 2009 the highest number of males and females was caught. In 2009 and 2012 males were caught more frequently (Table 1). Adults were more abundant than juveniles, and there were statistically significant differences in the number of adults and juveniles $(F=5.70, d$. f. $=1, P=$ $0.03)$. Adult males were recorded with greater frequency in the pre-reproductive and reproductive periods (Figure 3 ). Juveniles were recorded throughout sampling, though their frequency was low. Their abundance was greater and their emergence began in the pre-reproductive period. In 2008 and 2012 the number of juveniles recorded was highest. 
Table 1. Total number of Xerospermophilus perotensis caught, by sex, age and sampling year.

\begin{tabular}{rrrrr}
\hline & \multicolumn{2}{c}{ Female } & \multicolumn{2}{c}{ Male } \\
& Adult & Juvenile & Adult & Juvenile \\
\hline 2008 & 39 & 17 & 64 & 18 \\
2009 & 55 & 3 & 134 & 0 \\
2010 & 32 & 8 & 31 & 5 \\
2011 & 16 & 8 & 39 & 0 \\
2012 & 30 & 21 & 71 & 15 \\
2013 & 33 & 3 & 44 & 0 \\
2014 & 23 & 3 & 43 & 3 \\
\hline
\end{tabular}
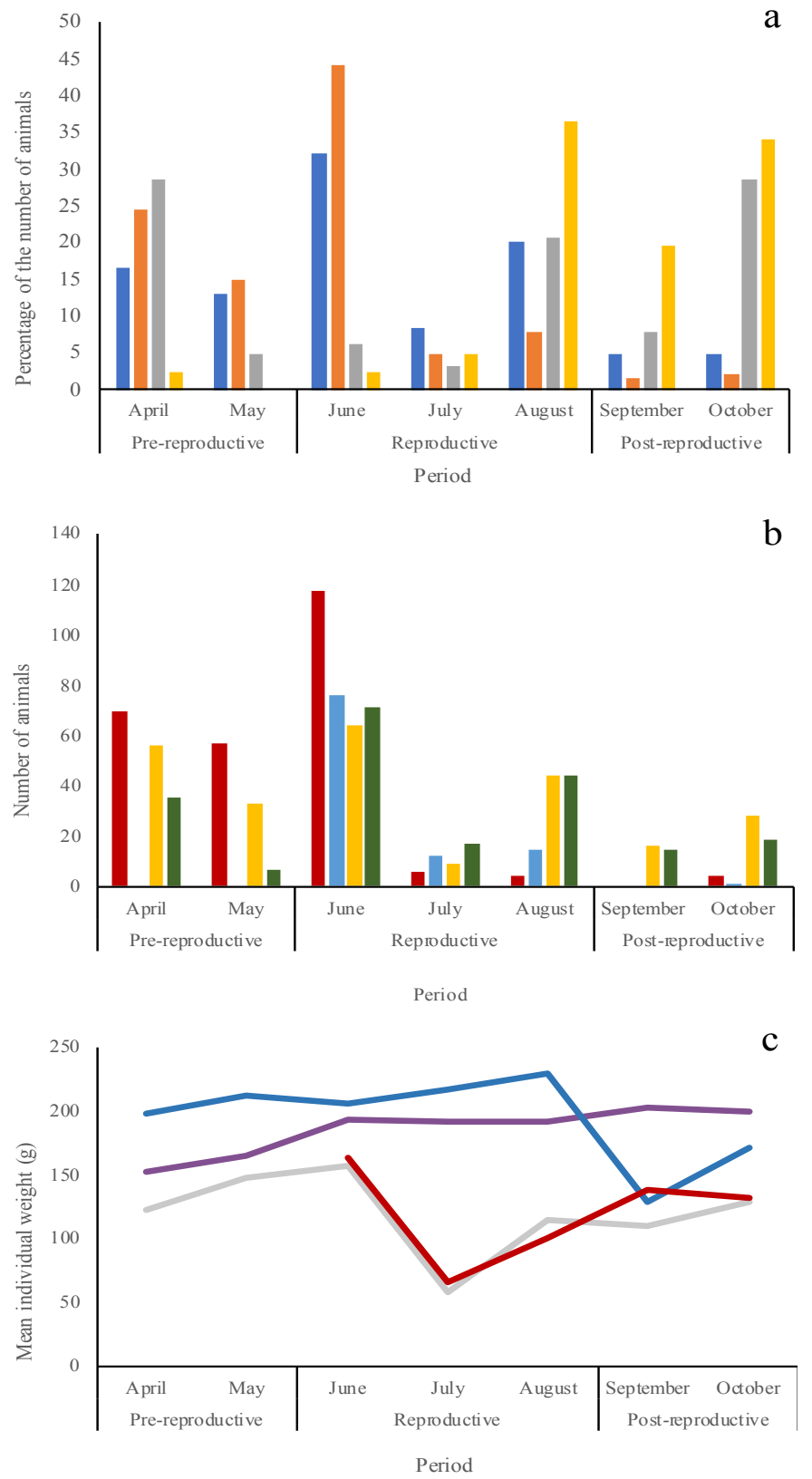

Figure 3. a) Sex and age ratios for the Perote ground squirrel (Xerospermophilus perotensis) recorded during its active cycle. Blue bars = adult females, orange bars = adult males, grey bars = juvenile males, yellow bars = juvenile males. b) Secondary sex characteristics of the Perote ground squirrel (Xerospermophilus perotensis) recorded during its active cycle. Red bars = scrotal testicles, blue bars = lacting / pregnant, yellow bars $=$ not pregnant, green bars $=$ abdominal testicles. c) Mean weight of the Perote ground squirrel (Xerospermophilus perotensis) by sex and age during its active cycle. Blue line $=$ adult males, purple line $=$ adult females, red line $=$ juvenile females, grey line $=$ juvenile males.
Regarding reproductive characteristics, scrotal males were most abundant and females with signs of pregnancy or lactating were recorded least often. Scrotal males were abundant starting in April, reached their maximum in June and decreased in July, when males with abdominal testes were more abundant (Figure 3). Non-pregnant females were recorded in all samples, with those showing signs of pregnancy or lactation appearing in June and through August, with similar values in July (12) and August (15).

The results of the chi-squared test indicate statistically significant differences in the number of adult males exhibiting secondary sex characteristics and those that did not during the three stages of the reproductive period $\left(X^{2}=\right.$ 56.28 , d. f. $=2, P<0.001)$ and in the number of females in different states (pregnant, not pregnant, lactating) over the same period $\left(X^{2}=28.09, \mathrm{~d}\right.$. f. $\left.=4, P<0.001\right)$. There were differences in the number of females that were not pregnant during the reproductive period $(\mathrm{F}=39.5, \mathrm{~d}$. $\mathrm{f} .=2, P<0.001)$, and the post hoc tests indicate differences between the preand post-reproductive period and with the reproductive and pre-reproductive period ( $P<0.001$ in both cases). There were differences in the number of pregnant females among study sites $(t=8.64, P<0.001)$, and differences in the number of lactating females between the reproductive and postreproductive periods ( $t=1.8, d$. f. $=21, P=0.03$ ). The number of scrotal males did not differ among periods (pre-, reproductive, post-; $\mathrm{F}=0.40$, d. f. $=2, P=0.66$, nor did the number of males with abdominal testicles ( $F=0.37, \mathrm{~d}$. $\mathrm{f} .=2, P=0.6)$.

The weight of the squirrels varied throughout the year. Adult males were heaviest during the pre-reproductive and reproductive periods and lightest during the post-reproductive period (Figure 3). Adult females were heaviest during the post-reproductive period and lightest in April. Juveniles weighed less during July, when they emerged, and their weight increased over the subsequent months.

There were no significant differences in weight between adult males and adult females ( $F=0.42$, d .f. $=1, P=0.5)$, and no differences in weight between male and female juveniles $(F=0.12$, d. f. $=1, P=0.7)$, though there were differences between adult and juvenile males $(F=11.79$, d. $f$. $=1, P=0.005)$ and between adult and juvenile females $(F=$ 21.4 , d. f. $=1, P<0.001)$.

\section{Discussion}

Our results reveal that the Perote ground squirrel exhibits phenological patterns similar to those described by Schwanz (2006) and by Williams and Lane (2014) for species belonging to the genus Ictidomys and Tamiasciurus since the species responds to changes in temperature and its activity cycle begins in the spring and ends in autumn. The highest environmental temperatures were recorded during the pre-reproductive period and marked the end of hibernation and the beginning of preparation for reproduction. When the temperature dropped, hibernation began; similar behaviours were reported for the Mexican ground squirrel (Schwanz 2006). Given that there is a statistically significant 
relationship between the squirrels' cycle and temperature, we infer that temperature is the most important phenological signal for the Perote ground squirrel, as observed with Urocitellus by Lane et al. (2012). While precipitation was not significantly related to the cycle of the Perote ground squirrel, it may exert some influence given that tropical storms and hurricanes originating in the Gulf of Mexico are a regular occurrence in the region (García 2003), and at times could prevent the animals from leaving their burrows. This could result in a low capture rate, as occurred in MendozaCarreón's (2009) study of this species.

The large number of male squirrels captured at the beginning of the year indicates that they were the first to emerge from hibernation. Michener (1983) reported the same pattern and indicates that this behaviour has the objective of obtaining the best territory and resources until the females emerge and reproduction occurs. The low number of captures at the end of the year reveals that the males were the first to enter hibernation, and this coincides with the findings of Holekamp and Sherman (1989), Michener (1983) and Castillo-Castillo (2009).

The results for secondary sex characteristics indicate they are related to temperature since their frequency was higher in April and June when temperatures were hottest and precipitation was not as intense as in other months. The records of these characteristics were lowest in August when the temperature begins to drop and rainfall is regular and heavy. Similar patterns have been reported in other studies (Best and Ceballos 1995; Valdez and Ceballos 1997; Castillo-Castillo 2009). In our study, scrotal males were the most abundant, a result that concurs with the findings of Castillo-Castillo (2009), and Montero-Bagatella and González-Romero (2014); this may result from their greater susceptibility to being captured. Males generally cover larger areas in their search for females to copulate with, as mentioned by Castillo-Castillo and González-Romero (2010). In contrast, females with signs of being pregnant were recorded least frequently, as occurred in the study by Montero-Bagatella and González-Romero (2014). This may result from the females staying in their burrows to attend to their young, allowing them to escape capture (MendozaCarreón 2009) or, as reported for other species of squirrel (Descamps et al. 2008; Kneip et al. 2011), because reproduction was not achieved.

For age category, the number of adults and juveniles differed statistically, with adults being more abundant throughout the study. Juveniles were more abundant during the post-reproductive period, likely because they were emerging from their burrows and beginning to explore the land as reported by Mendoza-Carreón's (2009). Their emergence coincided with the August peak in rainfall and is reflected in the growth of food resources that could benefit the squirrels development (Williams and Lane 2014). At the beginning of the year, juveniles were also recorded more frequently, as also reported by Castillo-Castillo (2009) and Mendoza-Carreón (2009), who mention that these val- ues are the result of squirrels that were born the previous year emerging from their burrows. In general, the number of records of juveniles was low, as observed in the study by Montero-Bagatella and González-Romero (2014), this can indicate that the populations are aging, that they are not being replenished, and are not growing, meaning that the possibilities for the recovery of this species are limited (Caughley and Sinclair 1994, Miller-Rushing et al. 2010). Kneip et al. (2011) mentioned that it is possible to underestimate juveniles because they disperse as they grow, so these numbers should be interpreted with some caution.

Hoogland (2003) and Schwanz (2006) demonstrated that in ground squirrels hibernation and reproduction require a notable energetic expenditure and this is reflected in the loss of body weight. This could be what happened to $X$. perotensis over the course of the study since, on emerging from hibernation, the animals encounter a change in food, refuge and habitat availability (Humphrey 1962). Reproduction requires a large energetic investment, more so by females that gestate and care for their young (Hoogland 2003; Yensen and Sherman 2003). Disturbances to the environment that occurred in some of the study sites were agricultural fires that get out of control and plowing, which can cause variations in the weight of the squirrels by limiting resource availability and increasing resource competition (Humphrey 1962).

The abundance of the Perote ground squirrel varied with temperature and precipitation. Increases in population may have been a response to heavy annual rains as documented in other studies of rodents (Kneip et al. 2011; Williams and Lane 2014; Heisler et al. 2014), since heavy rains can increase the yield of the grasses and asters that this species feeds on. If these conditions persist, they could result in an increase in population (Heisler et al. 2014). If however, conditions do not favour the ground squirrels, litter size may decrease, as observed in red squirrels (Descamps et al. 2008). The resources present in the habitat can therefore explain the frequencies of this squirrel, and limit or favor the population growth of the species.

The highest abundance values were recorded in April when the ground squirrels had come out of hibernation and were in their reproductive phase. In October, there were few captures, possibly because of low temperatures, resource scarcity and because it was the beginning of the hibernation period. Other studies on this species have reported similar results (Valdez and Ceballos 1997; CastilloCastillo 2009; Montero-Bagatella and González-Romero 2014). The abundance of the endemic Perote ground squirrel was greater in open sites and those with short grass such as sites 1, 2 and 3 (sampling years 2008 and 2009), because the species prefers this type of site, where it is easier for them to detect potential predators, move shorter distances to find refuge and find better resources such as territory and food (Heisler et al. 2014). Grass shoots are more nutritious and palatable and are optimal for the growth of these animals (Hannon et al. 2006; Yensen and Sherman 2003; 
Pasch and Koprowski 2011). These areas contrast with sites 6 and 7 (sampling years 2013 and 2014) where the pasture was dense and abundant, rendering them perhaps not as habitable as the other areas and resulting in a lower population estimate. In spite of the electric fence and surveillance at site 7, in June 2013, seven squirrels were lost; the traps had been moved from their locations and there were traces of blood and fur, suggesting the squirrels had been predated by dogs. This caused the decrease in abundance recorded in the subsequent months. For this species, the study of Castillo-Castillo (2009) reports maximum densities close to $50 \mathrm{ind} / \mathrm{ha}$, but for 2014 maximum density was 20 ind/ha (Montero-Bagatella and González-Romero (2014)). Based on the proposal of Yensen and Sherman (2003) that the minimum viable density for ground squirrels is $20 \mathrm{ind} /$ ha, we infer that the populations of $X$. perotensis have been decreasing and are small. Density indices overestimate values, in contrast to number of captures, which gives a real estimate of the population and is considered a more appropriate value for the purpose of conservation, especially for endangered species (Caughley and Sinclair 1994).

Even though the number of captures and the reported densities have different values, the tendencies of both parameters indicate steady population decreases in recent years; decreases caused by environmental disturbance, anthropogenic pressure and changes in resource availability (Hoffmann et al. 2003). Studies such as those of MendozaCarreón (2009) and Sánchez-Cordero et al. (2005) mention that the Perote ground squirrel has shown a certain degree of plasticity in the face of unfavourable conditions, though recent population studies indicate that it is now reaching its limit (Castillo-Castillo and González-Romero 2010; Montero-Bagatella and González-Romero 2014).

Ground squirrel density and precipitation can be considered demographic predictors for the purpose of conservation (Kneip et al. 2011), and precipitation can even be a predictor of survival rate (Bronson 1979). As such, these variables can be used for the proper management of this species, since the results show that its abundance values are low. This, in addition to its limited distribution, low dispersal capacity and the constant transformation and reduction of its habitat, confirms that $X$. perotensis is facing serious problems for survival, as highlighted in other studies of this species (Valdez and Ceballos 1997; Sánchez-Cordero et al. 2005; Álvarez-Castañeda et al. 2008; Castillo-Castillo 2009; Mendoza-Carreón 2009; Ochoa et al. 2012; MonteroBagatella and González-Romero 2014). Greater knowledge of this species, its population parameters and its ecology, will provide us with the tools required to better understand its protection and conservation needs. This, together with legal actions could save the species.

The conservation efforts of the private company Granjas Carroll de México, on whose land some animals were trapped, have allowed the populations of this species and others to develop. Also, the government of the state of Veracruz recently decreed a State Natural Conservation Area
(Gaceta Oficial 2016) that includes a small part of the distribution of this species. The sum of these actions, will benefit some populations of $X$. perotensis and over time could increase their populations. Another conservation strategy, as suggested by Montero Bagatella et al. (2017), would involve the local people, and would be based on environmental education plans, which allow the species to establish by preventing induced fires that destroy the resources that $X$. perotensis needs for to survive. Another strategy is to control feral dog populations, since they prey on it. Fences in the sampled areas would also reduce the risk of predation. Continuous anthropocentric development has considerably reduced the habitat available to this species, so ex situ conservation could also be considered, as long as the necessary guidelines for the conservation of the specimens are respected. From the results of our study, genetic studies are recommended in order to know how robust the genetic pool of extant populations is, and to effect the translocation of individuals as suggested by Ochoa et al. (2012). Based on the results of our study we consider that the status of this species under Mexican Legislation could be changed from "threatened" to "endangered".

\section{Acknowledgments}

S.H.M-B. is grateful to the Consejo Nacional de Ciencia y Tecnología for the award of a graduate studies scholarship (233712). The authors thank the Dirección General de Vida Silvestre for authorizing the permits required (SGPA/ DGVS/05833/08 and SGPA/DGVS/03369/15), and Granjas Carroll de México, S de R.L, de C.V., especially T. Tablada, H. Flores and N. Rosas. We are grateful to A. Sandoval for preparing the map. B. Delfosse translated the manuscript from the original in Spanish.

\section{Literature Cited}

Álvarez-Castañeda, S.T., I. Castro-Arellano, T. Lacher, and E. VAZQUEZ. 2008. Spermophilus perotensis. The IUCN Red List of Threatened Species. http://www.iucnredlist.org.

Arriaga, L., J. Espinoza, C. Aguilar, E. Martínez, L. Gómez, and E. LOA (EDS.). 2000. Regiones terrestres prioritarias de México, Comisión Nacional para el Conocimiento y uso de la Biodiversidad. Ciudad de México, México.

Best, T. L., AND G. Ceballos. 1995. Spermophilus perotensis. Mammalian Species 507:1-3.

Bradshaw W., and C. Holzapfel. 2007. Evolution of animal photoperiodism. Annual Review of Ecology Evolution and Systematics 38:1-25.

BRonson, M. T. 1970. Altitudinal variation in the life-history of the golden-mantled ground squirrel (Spermophilus lateralis). Ecology 60:272-279.

CASTILLO-CASTILLO, C. C. 2009. Densidad, estructura poblacional y hábitat de la ardilla endémica de Perote (Spermophilus perotensis Merriam, 1893). M. Sc. Thesis, Instituto de Ecología, A. C. Xalapa, México.

Castillo-Castillo, C. C., and A. González-Romero.2010. Áreas de actividad de la ardilla endémica de Perote Xerospermophilus perotensis. Therya 1:69-74. 
Caughley, G. 1977. Analysis of vertebrate populations. John Wiley \& Sons. New York, U. S. A.

Caughley, G, And A. Sinclair. 1994. Wildlife Ecology and Management. Blackwell Science. Cambridge, U. S. A.

Delgadillo, G. 2011. Distribución, selección de hábitat y densidad de la liebre torda (Lepus callotis, Wrangler, 1830) en el Valle de Perote. M. Sc. thesis, Instituto de Ecología, A. C. Xalapa, México.

Descamps, S., S. Boutin, D. Berteuaux, A. G. McAdam, and J. M. GAILLARD. 2008. Cohort effects in red squirrels: the influence of density, food abundance and temperature on future survival and reproductive success. Journal of Animal Ecology 77:305-314.

Dimmick, R. W, And M. R Pelton. 1996. Criteria of sex and age. $\mathrm{Pp}$ 169-214 in Research and management techniques for wildlife and habitats (Bookhout, T. A., ed.). The Wildlife Society. Bethesda, U. S. A.

GarCía, E. 2003. Distribución de la precipitación en la República Mexicana. Investigaciones Geográficas, Boletín del Instituto de Geografía. Universidad Nacional Autónoma de México 50:67-76.

Gaceta Oficial. Órgano del Gobierno del Estado de Veracruz de LA LLAVE. 2016. Decreto por el que se declara área natural protegida reserva ecológica San Antonio Limón Totalco en el Ejido San Antonio Limón Totalco, Municipio de Perote, Ver. Gobierno del Estado de Veracruz, Tomo CXCIV N0. 144 del 7 de noviembre de 2016. 1-27.

Gerez-Fernández, P. 1985. Uso del suelo durante cuatrocientos años y cambio fisionómico en la zona semiárida PoblanoVeracruzana, México. Biótica 10:123-144.

Gurnell, J., AND J. R. Flowerdew. 2006. Live trapping small mammals: a practical guide. Fourth edition. The Mammal Society. London, England.

Hannon, M., S. Jenkins, R. Crabtree, and A. Swanson. 2006. Visibility and vigilance: behavior and population ecology of Uinta ground squirrels (Spermophilus armatus) in different habitats. Journal of Mammalogy 87:287-295.

Heisler, L., C. Somers, And R. Poulin. 2014. Rodent populations on the northern Great Plains respond to weather variation at a landscape scale. Journal of Mammalogy 95:82-90.

Hoffmann, I., Milessi E., S. Huber, E. Lammina, and J. Dittami. 2003. Population dynamics of European ground squirrels (Spermophilus citellus) in a suburban area. Journal of Mammalogy 84:615-626.

Holekamp, K. 1984. Dispersal in ground-dwelling sciurids. Pp. 297320 in The biology of ground-dwelling squirrels (Murie, J., and G. Michener eds.). University of Nebraska Press. Lincoln, U. S. A.

Holekamp, K. E., and P. W Sherman. 1989. Why male ground squirrels disperse. American Scientist 77:232-239.

Hoogland, J. 2003. Sexual dimorphism of prairie dogs. Journal of Mammalogy 84:1254-1266.

Humphrey, R. R. 1962. Range ecology. The Ronald Press Company. New York, U. S. A.

Jones, C., W. J. McSheA, J. M. ConRoy, AND T. H. Kunz. 1996. Capturing Mammals. Pp 115-144 in Measuring and Monitoring Biological Diversity. Standard Methods for Mammals (Wilson D. E., F. R. Cole, J. D. Nichols, R. Rudran, and M. S. Foster eds.). Smithsonian Institution Press. Washington and London. U. S. A.

Kneip, E., D. H. Van Vuren, J. A. Hostetler, and K. O. Madan. 2011. Influence of population density and climate and the demography of subalpine golden-mantled ground squirrel. Journal of Mammalogy 92:367-377.

LANE, J. E. 2012. Delayed phenology and reduced fitness associated with climate change in a wild hibernator. Nature 489:554-557.

Miller-Rushing, A., T. Hoye, D. Inouye, And E. Post. 2010. The effects of phenological mismatches on demography. Philosophical Transactions of the Royal Society of London. Series B. Biological Sciences 365:3177-3186.

Montero-Bagatella, S. H., and A. González-Romero. 2014. Análisis demográfico de una especie en estado crítico: la ardilla de Perote. Therya 5:737-750.

Montero-Bagatella, S. H., GonzÁlez-Romero A., Gallina S. and G. SÁnchez-Rojas. 2017. Relación entre las características de la vegetación y las densidades de la ardilla de Perote. Revista Mexicana de Biodiversidad 88:691-700.

MicheneR, G. R. 1983. Spring emergence schedules and vernal behavior of Richardson's ground squirrels: why do males emerge from hibernation before females. Behavioral Ecology and Sociobiology 14:29-38.

Medina, M., And M. Angulo. 1990. Atlas climático del Municipio de Perote (Estado de Veracruz). Instituto de Ecología, A. C. Veracruz, México.

Mendoza-Carreón, G. 2009. Distribución y relaciones filogenéticas del moto (Spermophilus perotensis). M. Sc. Thesis, Instituto de Ecología, A. C.

OchoA, A., J. Gasca, G. Ceballos, and L. Eguiarte. 2012. Spatiotemporal population genetics of the endangered Perote ground squirrel (Xerospermophilus perotensis) in a fragmented landscape. Journal of Mammalogy 93:10611074.

PASCH, B., AND J. L Koprowski. 2011. Impacts of fire suppression on space use by Mexican fox squirrels. Journal of Mammalogy 92:227-234.

Sánchez-Cordero, V., P. Illoldi-Rangel, M. Linaje, S. Sarkar, and A. T. Peterson. 2005. Deforestation and extant distributions of Mexican endemic mammals. Biological Conservation 126:465-473.

SCHWANZ, L. E. 2000. Annual cycle of activity, reproduction and body mass in Mexican ground squirrels (Spermophilus mexicanus). Journal of Mammalogy 87:1086-1095.

Secretaría Del Medio Ambiente y Recursos Naturales (SEMARnat) and Comisión Nacional de Áreas Naturales Protegidas (CONANP). 2015. Programa de Manejo Parque Nacional Cofre de Perote o Nauhcampatépetl. México

Secretaría del Medio Ambiente y Recursos Naturales (SEMARNAT). 2010. Norma Oficial Mexicana NOM-059-SEMARNAT-2010, Protección ambiental-especies nativas de México de flora y fauna silvestre. Categorías de riesgo y especificaciones para su inclusión, exclusión o cambio. Lista de especies en riesgo. Diario Oficial de la Nación (Segunda sección). Ciudad de México, México.

Sikes, R. S., W. L. Gannon, and The Animal Care and Use Committee of The American Society of Mammalogists. 2016. Guidelines of The American Society of Mammalogists for the use of Wild Mammals in Research. Journal of Mammalogy 97:663-688.

Valdez, M., and G. Ceballos. 1997. Conservation of endemic mammals of Mexico: the Perote ground squirrel (Spermophilus perotensis). Journal of Mammalogy 78:74-82. 
Valdez, M. and G. Ceballos. 2003. Patrones de hibernación de ardillas de tierra (Spermophilus mexicanus y S. perotensis) en el centro de México. Revista Mexicana de Mastozoología 7:40-48.

VAN HoRnE, B. 1983. Density as a misleading indicator of habitat quality. The Journal of Wildlife Management 47:893: 901.

Williams, C. T., AND J. E LANE. 2014. Reproductive phenology of a food-hoarding mast-seed consumer: resource and densitydependent benefits of early breeding in red squirrels. Oecologia 174:777-788.

Yensen, E., and P. W Sherman. 2003. Ground squirrels: Spermophilus and Amnospermophilus species. Pp. 211-231 in Wild Mammals of North America: Biology, Management and Conservation (Feldhamer G. A, B. C. Thomson, and J. A. Chapman eds.). 2nd edn. The Johns Hopkins University Press. Baltimore, U.S. A.

ZAR, J. H. 1999. Bioestatistical analysis. 4th Ed. Prentice Hall. Englewood Cliffs, U. S. A.

Associated editor: Guillermo D'Elia

Submitted: October 10, 2017; Reviewed: November 18, 2017;

Accepted: March 24, 2018; Published on line: April 24, 2018. 